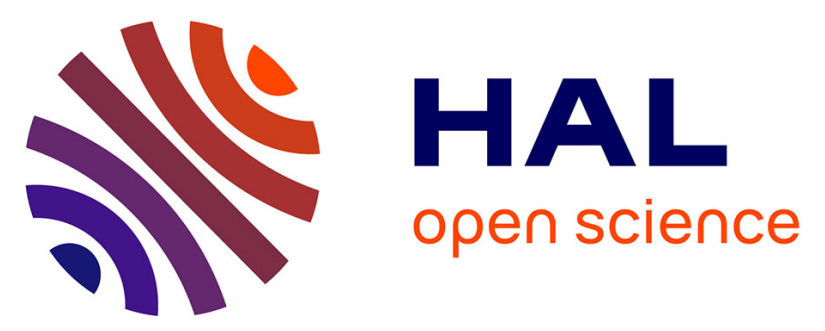

\title{
Comparative environmental assessment of valorization strategies of the invasive macroalgae Sargassum muticum
}

Paula Perez-Lopez, Elena M. Balboa, Sara Gonzalez-Garcia, Herminia

Dominguez, Gumersindo Feijoo, Maria Teresa Moreira

\section{- To cite this version:}

Paula Perez-Lopez, Elena M. Balboa, Sara Gonzalez-Garcia, Herminia Dominguez, Gumersindo Feijoo, et al.. Comparative environmental assessment of valorization strategies of the invasive macroalgae Sargassum muticum. Bioresource Technology, 2014, 161, pp.137-148. 10.1016/j.biortech.2014.03.013 . hal-01284826

\section{HAL Id: hal-01284826 \\ https://hal.science/hal-01284826}

Submitted on 22 Aug 2017

HAL is a multi-disciplinary open access archive for the deposit and dissemination of scientific research documents, whether they are published or not. The documents may come from teaching and research institutions in France or abroad, or from public or private research centers.
L'archive ouverte pluridisciplinaire HAL, est destinée au dépôt et à la diffusion de documents scientifiques de niveau recherche, publiés ou non, émanant des établissements d'enseignement et de recherche français ou étrangers, des laboratoires publics ou privés. 


\title{
Comparative environmental assessment of valorization strategies of
}

\section{the invasive macroalgae Sargassum muticum}

\author{
Paula Pérez-López ${ }^{1, *}$, Elena M. Balboa ${ }^{2}$, Sara González-García ${ }^{1}$, Herminia Domínguez², \\ Gumersindo Feijoo ${ }^{1}$ and $\mathrm{M}^{\mathrm{a}}$ Teresa Moreira ${ }^{1}$
}

${ }^{1}$ Department of Chemical Engineering, Institute of Technology, University of Santiago de Compostela. 15782 - Santiago de Compostela, Spain

${ }^{2}$ Department of Chemical Engineering, Faculty of Sciences, University of Vigo, As Lagoas s/n, 32004 Ourense, Spain

\begin{abstract}
The invasive brown seaweed Sargassum muticum (Yendo) exhibits a significant content of phenolic compounds, polysaccharides and fucoxanthin, with potential biological activities. In this study, four valorization strategies for S. muticum biomass were compared under a life cycle perspective. Depending on the alternative, three products were obtained: sodiumalginate, antioxidant extract and fucoxanthin-containing extract. Regardless of the approach, the combined extraction of alginate and antioxidant from wet algae constituted the most efficient scenario. Among the stages, supercritical extraction of fucoxanthin and non-isothermal autohydrolysis were identified as the major environmental burdens due to electricity consumption. Although changes in product distribution fairly affected the environmental impacts of the scenarios, the single extraction of antioxidant fraction and the integral valorization to obtain fucoxanthin, alginate and antioxidant were only competitive when considering a functional unit based on the
\end{abstract}


value of the products through an economic allocation approach instead of the amount of valorized algae.

Keywords Antioxidant, alginate, fucoxanthin, life cycle assessment, invasive macroalgae

\section{Introduction}

Invasive macroalgae are currently considered a major threat to native species and ocean's resources worldwide (Schaffelke et al., 2006). The introduction of non-indigenous species may affect the existing habitats due to shifts in communities and trophic chains, which results in the decline of biodiversity and the alteration of the ecological stability of invaded ecosystems (Walker and Kendrick, 1998). Although biological invasion takes place naturally, anthropological activities such as heavy naval traffic, import of shellfish products or aquaculture have sharply accelerated this process and made it more frequent in both terrestrial and marine ecosystems over the last decades (Anderson, 2007; Schaffelke et al., 2006; Walker and Kendrick, 1998). Therefore, different strategies have been studied in order to control and prevent the proliferation of invasive species with different outcomes, essentially based on several mechanical removal procedures, but even considering the use of heat, chemicals (copper, chlorine, salt) or biological control by herbivorous mollusks (Anderson, 2007).

Sargassum muticum (Yendo) Fensholt is an invasive brown seaweed native to Japan which was introduced in North America by 1940s and in Europe during 1970s (Kraan, 2008; Walker and Kendrick, 1998). Nowadays, due to its extensive reproductive capacity, S. muticum is almost worldwide distributed, including different areas of the Pacific coast from Alaska to Mexico, the North Sea (Belgium, Denmark, the Netherlands...), major areas in Portugal, Spain, France and Ireland, as well as the English Channel coast or the Mediterranean Sea (Davis et al., 2004; 
Kraan, 2008). Moreover, several studies have already highlighted the effect that S. muticum has on native communities (Britton-Simmons, 2004; Kraan, 2008). Although the influence on other species is limited in the foreshore, native populations are strongly affected by the organism according to studies in the subtidal zone (deepest area of the shore), probably related to shading effects (Britton-Simmons, 2004).

Due to the ecological problems caused by Sargassum sp, seasonal harvesting appears as an alternative to control algae proliferation (Kraan, 2008). Nevertheless, this measure entails the accumulation of large quantities of biomass that needs to be treated or utilized for valuable applications. The potential valorization of the resulting biomass lies in the capability of Sargassum sp to produce numerous high-value compounds with potential pharmaceutical applications. Particularly S. muticum exhibits a significant amount of phenolic compounds with biological activities, such as antifouling or antioxidant properties (González-López et al., 2012; Plouguerné et al., 2010). In addition, the seaweed contains polysaccharides, namely alginate and fucoidans, which justify its widespread use for metal biosorption (Davis et al., 2004), but also make it a good candidate in food, pharmaceutical or cosmetics sectors due to properties such as antioxidant, anticoagulant, antithrombic, antitumor and antiviral activities (Balboa et al., 2013).

Moreover, S. muticum also contains low amounts of the xanthophyll fucoxanthin, a yellowish pigment with promising applications based on its antioxidant, anti-inflammatory, anticancer, anti-obese, antidiabetic and antiangiogenic activities, as well as protective effect in several organs (Balboa et al., 2013; Conde et al., 2012).

The use of these functional compounds from macroalgae requires the selection of a suitable extraction method, according to several criteria such as selectivity, cost-effectiveness and environmental performance (Kadam et al., 2013). Regarding phenolic compounds, the total 
content and its antioxidant activity is highly dependent on the chosen method (Kadam et al., 2013). Solvent extraction is the most widely used technique for this purpose, though it requires long extraction times as well as the use of aqueous organic solvents such as methanol, ethanol and acetone (García-Salas et al., 2010; Kadam et al., 2013). Therefore, alternative methods have been proposed such as supercritical fluid extraction, pressurized liquid extraction or ultrasoundassisted extraction (García-Salas et al., 2010). In the case of alginate, the standard extraction method consists of a neutral extraction by performing a pre-extraction with hydrochloric acid to obtain an alginic acid that is then neutralized by adding sodium hydroxide and finally precipitated with sodium chloride and ethanol. Other methods have also been applied with comparable results in terms of alginate yield, including alkaline extraction at room and high temperatures (Davis et al., 2004). With respect to polysaccharides, traditional techniques are also time-consuming and require large amounts of organic solvents for precipitation, so more recent methods for separation include novel technologies such as supercritical extraction, ultrasonicassisted extraction and membrane separation (Ye et al., 2008). Organic solvent extraction is again the most frequent method to separate fucoxanthin from seaweeds, with methanol, ethanol or acetone as common solvents (Conde et al., 2012). However, apart from the aforementioned environmental problems, in this case solvents can damage the functional properties of the extract, so supercritical fluid extraction has been suggested as a more selective technology that allows obtaining an extract with fewer polar impurities and, therefore, an easier subsequent purification procedure (Conde et al., 2012).

In this study, the processing scheme described by González-López et al. (2012) as well as three additional configurations based on modifications of the first approach were evaluated from an environmental perspective with the aim of identifying the most suitable valorization route. 
The process consisted of consecutive extraction stages of the valuable biologically active compounds (fucoxanthin-containing extract by supercritical fluid extraction, alginate by alkaline extraction and antioxidant extract by non-isothermal autohydrolysis) to achieve an integral utilization of S. muticum.

Life Cycle Assessment (LCA) standardized methodology was used to evaluate the environmental aspects and potential impacts of the process (ISO 14040, 2006). This methodology has already been applied in a small number of studies related to the potential of macroalgal biomass as a feedstock in the production of biogas and bioethanol (Alvarado-Morales et al., 2013; Aresta et al., 2005). Although the production of high value bioactive molecules from other marine sources has also been evaluated through a LCA perspective (Pérez-López et al., 2014), there are no available studies focused on the production of these biocompounds from macroalgae harvested from nature.

\section{Methods}

\subsection{Goal and scope definition}

This study aims at identifying the environmental profile associated with the valorization of the invasive macroalgae $S$. muticum in four different scenarios. The main goal is to determine the most sustainable route, from an environmental point of view, to utilize $S$. muticum biomass. The compared processes were evaluated according to a cradle to gate perspective, including the production of the different inputs to the system, as well as the harvesting of macroalgal biomass, cleaning and preparation of the harvested biomass and further extraction and purification. Depending on the selected alternative, three main products were obtained: sodium alginate, 
antioxidant extract and fucoxanthin-containing extract. Additionally, the remaining algal residue resulting from each process was considered as subproduct due to its potential use as fertilizer.

\subsubsection{Functional unit}

One of the key parameters to select when performing a LCA is the functional unit (FU) or reference value to which inputs and outputs to the system and environmental impacts are expressed. FU shall therefore reflect the function of the studied system and its choice strongly depends on the aim of the study (Schau and Fet, 2008). In this case, the purpose of the process was to valorize an existing biomass that otherwise would have to be treated as a waste. From this perspective, $1 \mathrm{~kg}$ of final valorized biomass was selected as the FU.

\subsubsection{System boundaries}

The system under study consisted of six main subsystems: harvesting of the macroalgae from the natural environment (S1), pretreatment for extraction (S2), supercritical extraction of fucoxanthin-containing extract (S3), extraction of alginate from the algal biomass (S4), precipitation of alginate (S5) and non-isothermal autohydrolysis to obtain the antioxidant extract (S6). Only subsystems S1, S2 and S6 were common to the four analyzed scenarios; whereas S3 was only performed when fucoxanthin-containing extract was one of the target products and S4 and S5 were not required in case alginate was not extracted. The subsystems and unit processes included within the system boundaries are depicted in Figure 1 and described below.

\subsubsection{Harvesting of the macroalgae from the natural environment (S1)}

The collection was carried out by two methods consisting of (i) direct manual harvesting of macroalgae that arrived at the beach due to tides or (ii) collection from the sea by boat. The amount of biomass collected by each procedure was estimated as $20 \%$ by boat and $80 \%$ at the beach (Manuel Loureiro, Conservas y Ahumados Lou SL, March 2013, personal 
communication). The system boundaries include the materials and fuel, as well as emissions to environment associated with vessel operations for the collection. In addition, water to clean and rinse the collected biomass to remove impurities (sand, epiphytes...) was considered, as well as the use of polyethylene and nylon for nets.

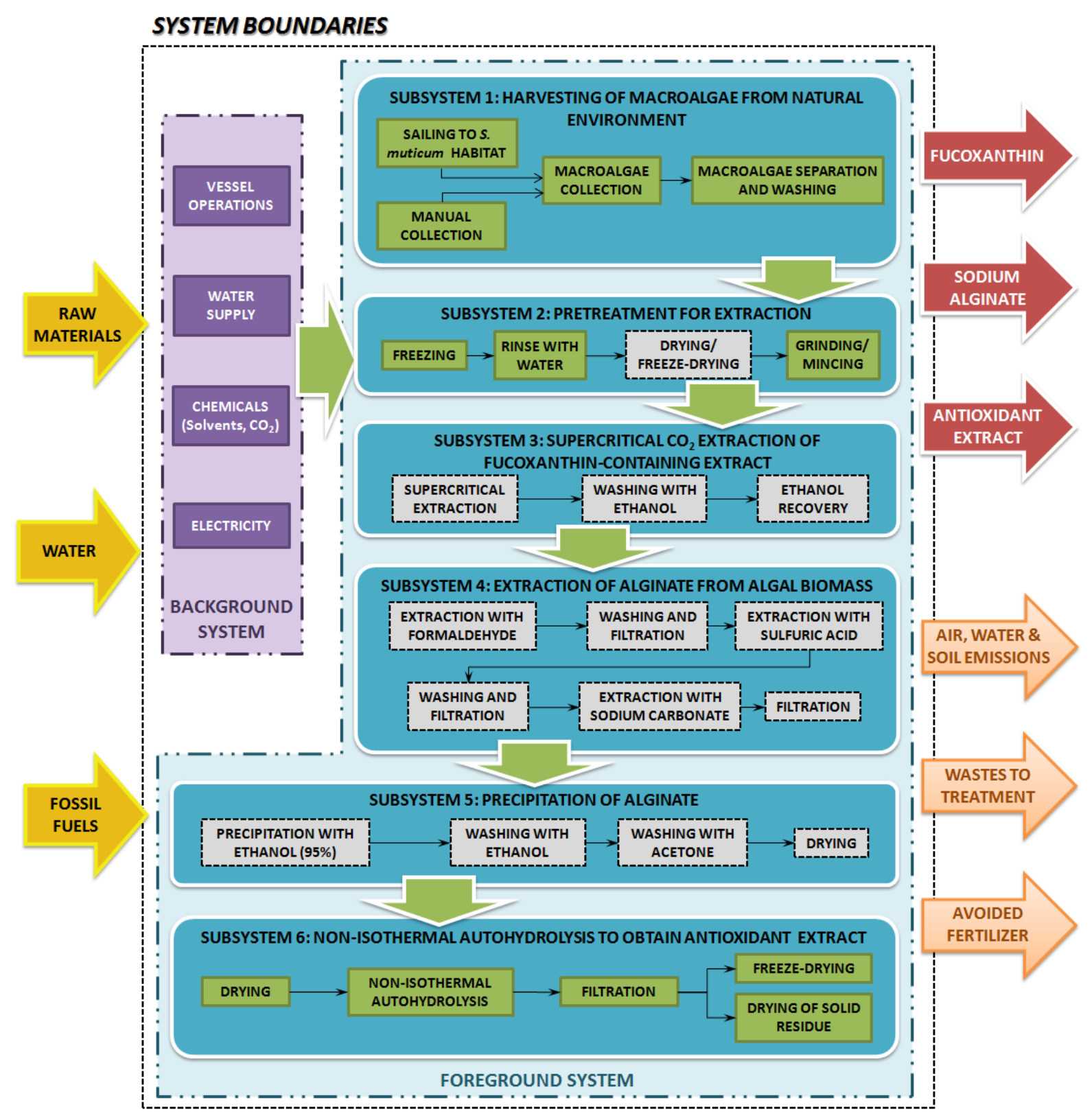


Figure 1 Process chain and system boundaries of the integral valorization of the macroalga Sargassum muticum by sequential extraction of fucoxanthin-containing extract, alginate and antioxidant extract (blocks in grey with discontinuous lines refer to steps that are not common to the four assessed scenarios).

\subsubsection{2. $\quad$ Pretreatment for extraction (S2)}

The clean biomass was kept in the freezer for a week (as average) before additional rinsing with water. The next stage depended on the considered scenario: in the base scenario (Sc 1), the algal biomass was dried in oven for $2 \mathrm{~h}$ before grinding it for $1 \mathrm{~h}$. This stage was initially proposed since some algal canning factories use this procedure to process algae for food uses. This option would facilitate room storage of algae. Experimental work showed the possibility to perform the extractions with wet algae, so drying stage was not considered in Sc 2 and Sc 3, and grinding was substituted by mincing. Finally, when carrying out the supercritical extraction before alginate and antioxidant extractions (Sc 4), biomass had to be previously freeze-dried and ground.

\subsubsection{Supercritical extraction of fucoxanthin-containing extract (S3)}

This subsystem is only included in Sc 4. In this scenario, a limited portion of the fucoxanthin contained in the biomass (12 $\mathrm{mg}$ from a total of $55.1 \mathrm{mg}$ fucoxanthin per $100 \mathrm{~g}$ dry weight macroalgal biomass) was separated through supercritical $\mathrm{CO}_{2}$ extraction $(\mathrm{P}=20-40 \mathrm{MPa}$ and $\mathrm{T}$ $=40-55^{\circ} \mathrm{C} ; 140 \mathrm{~kg} \mathrm{CO} 2 / \mathrm{kg}$ valorized biomass with no recycling system), using ethanol as cosolvent $(21 \mathrm{~L} / \mathrm{kg}$ valorized algae with no recovery system) and operating the system for $1 \mathrm{~h}$. In this case, $90 \%$ recovery and reuse of both $\mathrm{CO}_{2}$ and ethanol were assumed. The obtained extract contained 5-10\% fucoxanthin.

\subsubsection{Extraction of alginate from algal biomass (S4)}


In all scenarios except for Sc 3, the remaining algal biomass was then extracted at room temperature with consecutive additions of formaldehyde $1 \%(15 \mathrm{~h})$, sulfuric acid $0.2 \mathrm{~N}(4 \mathrm{~h})$ and sodium carbonate $1 \%(15 \mathrm{~h})$ in a sequential process with intermediate filtrations and washings of solids using distilled water. Stirring in all the extractions was also included within the system boundaries.

\subsubsection{Precipitation of alginate (S5)}

Once the liquid fraction containing sodium alginate (11.4\% algal biomass in dry weight) was separated, a precipitation process was performed. The process consisted of the addition of ethanol 95\% (15 min stirring, $1 \mathrm{~h}$ resting) and a washing step with absolute ethanol and acetone, followed by a drying step in oven. A solvent recovery of $90 \%$ was assumed for ethanol (total consumption of $106 \mathrm{~L} / \mathrm{kg}$ valorized algae with no recovery system), whereas no acetone recovery was considered due to the low need for this solvent $(8 \mathrm{~L} / \mathrm{kg}$ valorized algae).

\subsubsection{Non-isothermal autohydrolysis to obtain antioxidant extract (S5)}

The solid fraction obtained after the last filtration in S4 (or after mincing in S2 for Sc 3) was rich in antioxidant extract. In the four scenarios, this solid was dried for two days in an oven at $50^{\circ} \mathrm{C}$ and treated with water in a batch reactor under non-isothermal conditions (final temperature of $170^{\circ} \mathrm{C}$, which renders to the maximum content in fucoidans within the extract that corresponds

to $20-30 \%$ of the product) at a liquid/solid ratio of $60: 1 \mathrm{~g} \mathrm{~g}$ _1. Once the selected temperature was reached, the biomass was kept in the reactor for $30 \mathrm{~min}$ and then cooled to $50-60^{\circ} \mathrm{C}$ and opened. The antioxidant extract ( $21 \%$ algal biomass in dry weight) was recovered by filtration and freeze-dried, whereas the algal paste with potential use as fertilizer was dried in oven for two days. 


\subsubsection{Evaluated scenarios}

The evaluated extraction routes, schematized in Figure 2, were:

- Scenario 1 (Sc 1): Base scenario described by González-López et al. (2012), consisting of the valorization of dry algal biomass by alkaline extraction and precipitation of alginate followed by a non-isothermal autohydrolysis to separate an antioxidant extract rich in phenolics and polysaccharides, with potential applications in cosmetics industry.

- Scenario 2 (Sc 2): Valorization of wet algal biomass by alkaline extraction and precipitation of alginate followed by a non-isothermal autohydrolysis to separate the antioxidant extract.

- Scenario 3 (Sc 3): Valorization of wet algal biomass by non-isothermal autohydrolysis to obtain the antioxidant extract.

- Scenario 4 (Sc 4): Integral valorization of freeze-dried algal biomass based on the supercritical fluid extraction of fucoxanthin-containing extract followed by alkaline extraction and precipitation of alginate as well as non-isothermal autohydrolysis to obtain the antioxidant extract.

The protocols for the different alternatives of separation and purification were developed by the Group EQ2 of Chemical Engineering (www.grupoeq2.es) in the Faculty of Sciences in Ourense, at the University of Vigo (Spain). 
Sc 1. Dry algal biomass to alginate + antioxidant extract

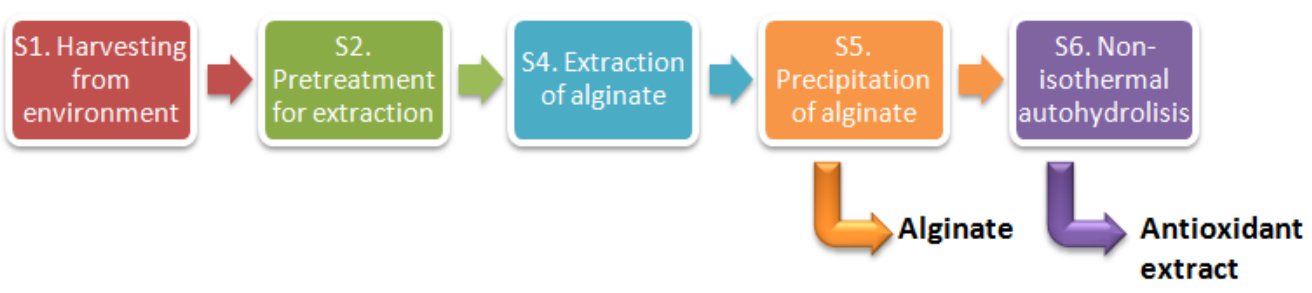

Sc 2. Wet algal biomass to alginate + antioxidant extract

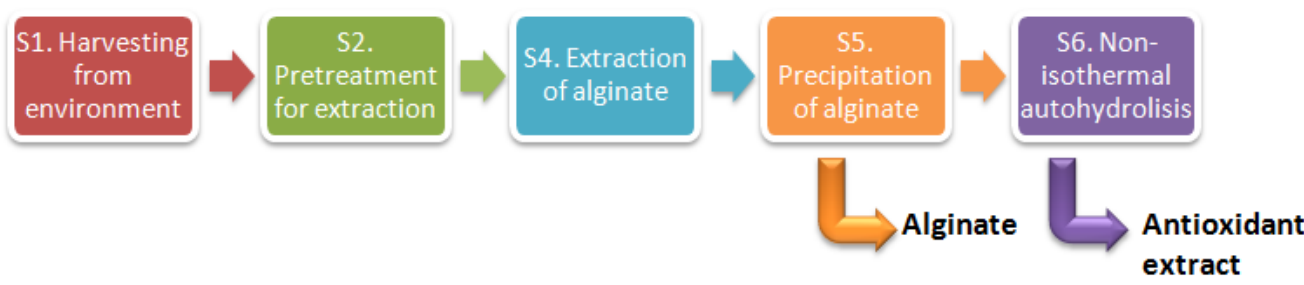

Sc 3. Wet algal biomass to antioxidant extract

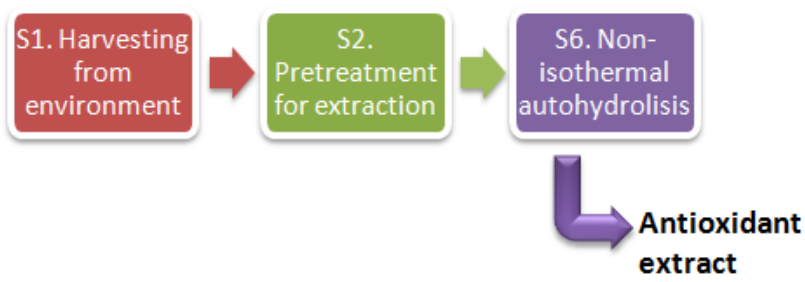

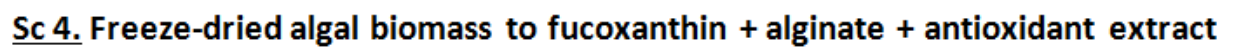

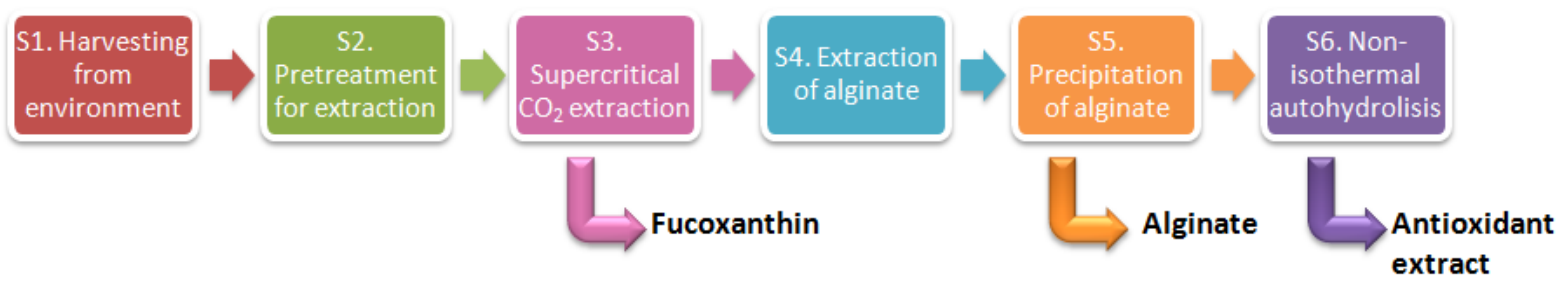

Figure 2 Schematic view of the stages performed and products obtained in each of the compared scenarios.

2.2 Inventory analysis, data quality and assumptions

Life Cycle Inventory (LCI) stage requires the collection of high quality data, which are essential for a reliable assessment. In this case, foreground data for the six subsystems were collected from different sources and procedures, as indicated in Table $\mathbf{1 .}$

Table 1 Summary of data sources for foreground system. 


\begin{tabular}{|c|c|c|}
\hline Subsystem & Data required & Data sources \\
\hline \multirow{10}{*}{$\begin{array}{l}\text { S1. Collection from natural } \\
\text { environment }\end{array}$} & Polyester & \multirow{2}{*}{$\begin{array}{l}\text { Manufacturers' specifications, personal } \\
\text { communication, Hospido and Tyedmers } \\
(2005) \text {. }\end{array}$} \\
\hline & Steel & \\
\hline & Antifouling & \multirow{3}{*}{$\begin{array}{l}\text { Manufacturers' specifications, Vázquez-Rowe } \\
\text { et al (2010). }\end{array}$} \\
\hline & Paint & \\
\hline & Lubricant oil & \\
\hline & Tap water & $\begin{array}{l}\text { Personal communication, according to } \\
\text { consumption at canning facility. }\end{array}$ \\
\hline & Polyethylene (LDPE) & \multirow{2}{*}{ Experimental data, on-site measurement. } \\
\hline & Nylon & \\
\hline & Emissions & $\begin{array}{l}\text { Estimated according to Vázquez-Rowe et al } \\
\text { (2010), Hospido and Tyedmers (2005). }\end{array}$ \\
\hline & Wastes to treatment & Calculated from mass balances. \\
\hline \multirow{3}{*}{$\begin{array}{l}\text { S2. Pretreatment for } \\
\text { extraction }\end{array}$} & Tap water & Experimental data, on-site measurement. \\
\hline & $\begin{array}{l}\text { Electricity } \\
\text { consumption }\end{array}$ & $\begin{array}{l}\text { Estimated from power of equipment and } \\
\text { duration of stage. }\end{array}$ \\
\hline & Emissions & Calculated from mass balances. \\
\hline \multirow{4}{*}{$\begin{array}{l}\text { S3. Supercritical extraction } \\
\text { of fucoxanthin-containing } \\
\text { extract }\end{array}$} & Ethanol & \multirow{2}{*}{$\begin{array}{l}\text { Experimental data, on-site measurement. } \\
\text { Assumed recovery or recirculation. }\end{array}$} \\
\hline & Carbon dioxide & \\
\hline & $\begin{array}{l}\text { Electricity } \\
\text { consumption }\end{array}$ & $\begin{array}{l}\text { Estimated from power of equipment and } \\
\text { duration of stage. }\end{array}$ \\
\hline & Emissions & Calculated from mass balances. \\
\hline \multirow{7}{*}{$\begin{array}{l}\text { S4. Separation of alginate } \\
\text { from antioxidant fraction }\end{array}$} & Tap water & \multirow{5}{*}{$\begin{array}{l}\text { Experimental data, on-site measurements. } \\
\text { Gonzalez-López et al. (2012). }\end{array}$} \\
\hline & Distilled water & \\
\hline & Formaldehyde & \\
\hline & Sulfuric acid & \\
\hline & Disodium carbonate & \\
\hline & $\begin{array}{l}\text { Electricity } \\
\text { consumption }\end{array}$ & $\begin{array}{l}\text { Estimated from power of equipment and } \\
\text { duration of stage. }\end{array}$ \\
\hline & Emissions & Calculated from mass balances. \\
\hline \multirow{4}{*}{ S5. Precipitation of alginate } & Ethanol & \multirow{2}{*}{$\begin{array}{l}\text { Experimental data, on-site measurements. } \\
\text { Gonzalez-López et al. (2012). }\end{array}$} \\
\hline & Acetone & \\
\hline & $\begin{array}{l}\text { Electricity } \\
\text { consumption }\end{array}$ & $\begin{array}{l}\text { Estimated from power of equipment and } \\
\text { duration of stage. }\end{array}$ \\
\hline & Emissions & Calculated from mass balances. \\
\hline \multirow{3}{*}{$\begin{array}{l}\text { S6. Non isothermal } \\
\text { autohydrolysis to obtain } \\
\text { antioxidant extract }\end{array}$} & Distilled water & Experimental data, on-site measurements. \\
\hline & $\begin{array}{l}\text { Electricity } \\
\text { consumption }\end{array}$ & $\begin{array}{l}\text { Estimated from power of equipment and } \\
\text { duration of stage. }\end{array}$ \\
\hline & Emissions & Calculated from mass balances. \\
\hline
\end{tabular}

The inputs for the collection of biomass from natural environment (S1), including fuel consumption, as well as materials of the vessel and chemicals associated with maintenance, were obtained from manufacturers' specifications and personal communications with expert advisors. 
Materials for the vessel were estimated according to average dimensions and weights. A shared used of the boat was considered ( $1600 \mathrm{~h}$ per year) and three months of operation were considered associated with the seasonal harvest of the macroalgae $(480 \mathrm{~h})$. Materials for hull and engine were increased by $25 \%$ and $50 \%$ respectively, and life spans of 30 and 15 years were considered, according to Hospido and Tyedmers (2005). Chemicals related to vessel operations (i.e. paint, antifouling paint, marine lubricant oil), as well as water and air emissions from fuel combustion discharged to the environment were inventoried according to Vázquez-Rowe et al. (2010), considering manufacturers' specifications. For paint and anti-fouling emitted to marine environment, a loss of two thirds of the total amount used was considered (Hospido and Tyedmers, 2005).

For the next subsystems (S2 to S6), chemicals and water consumptions were estimated from experimental data obtained by on-site measurements and completed with information from González-López et al. (2012). Electricity consumptions were extrapolated on the basis of the power of the equipment, processing capacity and duration of each stage. As the inventory is associated with a hypothetical facility placed in shore, transport of equipments and chemicals was considered negligible. Water and air emissions were calculated on the hypothesis that the chemicals which are not consumed during the process are directly discharged.

Concerning the background system, the corresponding inventory data for the production of all the inputs to the system were taken from Ecoinvent database. These inputs included the production of chemicals required for the extraction stages, the production of electricity used within the stages of the process, as well as the materials for the vessel needed for the algae collection and waste disposal. A detailed description of the corresponding database reports considered is shown in Table 2. 
Table 2 Summary of data sources for background system

\begin{tabular}{|c|c|c|}
\hline \multirow[b]{2}{*}{ Energy } & Diesel & Ecoinvent database (Jungbluth 2007) \\
\hline & $\begin{array}{l}\text { Electricity (Spanish electricity } \\
\text { profile) }\end{array}$ & Ecoinvent database (Dones et al. 2007) \\
\hline \multirow{3}{*}{$\begin{array}{l}\text { Chemicals related } \\
\text { to vessel } \\
\text { operation }\end{array}$} & Anti-fouling & \multirow{3}{*}{ Vázquez-Rowe et al. (2010) } \\
\hline & Boat paint & \\
\hline & Marine lubricant oil & \\
\hline \multirow{4}{*}{$\begin{array}{l}\text { Materials for } \\
\text { collection from } \\
\text { natural } \\
\text { environment }\end{array}$} & $\begin{array}{l}\text { Glass fibre reinforced plastic, } \\
\text { polyester resin }\end{array}$ & Ecoinvent database (Kellenberger et al 2007) \\
\hline & Steel & Ecoinvent database (Classen et al. 2007) \\
\hline & Polyethylene & \multirow{2}{*}{ Ecoinvent database (Hischier 2007) } \\
\hline & Nylon & \\
\hline \multirow{6}{*}{ Chemicals } & Formaldehyde & \multirow{4}{*}{ Ecoinvent database (Althaus et al. 2007) } \\
\hline & Sulfuric acid & \\
\hline & Acetone & \\
\hline & Carbon dioxide & \\
\hline & Sodium carbonate & Ecoinvent database (Sutter 2007a) \\
\hline & Ethanol & Ecoinvent database (Sutter 2007b) \\
\hline \multirow{2}{*}{ Water supply } & Tap water & \multirow{2}{*}{ Ecoinvent database (Althaus et al. 2007) } \\
\hline & Distilled water & \\
\hline \multirow{3}{*}{ Waste treatment } & Inert landfill & \multirow{3}{*}{ Ecoinvent database (Doka 2007) } \\
\hline & Sanitary landfill & \\
\hline & Municipal incineration & \\
\hline \multirow{2}{*}{$\begin{array}{l}\text { Avoided product: } \\
\text { fertilizer }\end{array}$} & Ammonium sulfate & \multirow{2}{*}{ Ecoinvent database (Nemecek and Kägi 2007) } \\
\hline & Municipal incineration & \\
\hline
\end{tabular}

Finally, all the scenarios allow obtaining a biomass residue with potential applications as fertilizer. To do so, the content in carbon and nitrogen, as well as the ratio $\mathrm{C} / \mathrm{N}$ were determined. The measured content of carbon was $45.6 \pm 0.2 \%$ (dry weight) and the content of nitrogen was $1.5 \pm 0.2 \%$ (dry weight). Since the obtained $\mathrm{C} / \mathrm{N}$ ratio is higher than 25 , all the nitrogen present in the residual biomass can be uptaken by the plants. Once the fertilizer potential was estimated, the equivalent amount of a typical fertilizer (containing ammonium sulfate as $\mathrm{N}$ source) was considered in the model as avoided product, which resulted in negative impacts that were subtracted from the environmental burdens.

The global inventory of the four assessed scenarios is shown in Table 3. According to the selected FU (1 kg valorized algae), no allocation procedure was required. 
Table 3. Global inventory table for the valorization of invasive macroalga $S$. muticum (FU: $1 \mathrm{~kg}$ valorized biomass)

\begin{tabular}{|c|c|c|c|c|}
\hline \multicolumn{5}{|c|}{ INPUTS from TECHNOSPHERE } \\
\hline & $\begin{array}{l}\text { Sc 1. Alginate + } \\
\text { antioxidant } \\
\text { extract from dry } \\
\text { alga }\end{array}$ & $\begin{array}{l}\text { Sc 2. Alginate } \\
+ \text { antioxidant } \\
\text { extract from } \\
\text { wet alga }\end{array}$ & $\begin{array}{l}\text { Sc } 3 \text {. } \\
\text { Antioxidant } \\
\text { extract from } \\
\text { wet alga }\end{array}$ & $\begin{array}{l}\text { Sc } 4 \text {. Fucoxanthin- } \\
\text { containing extract }+ \\
\text { alginate+ antioxidant } \\
\text { extract from freeze- } \\
\text { dried alga }\end{array}$ \\
\hline \multicolumn{5}{|l|}{ Materials } \\
\hline Polyester & \multicolumn{2}{|c|}{$65.37 \mathrm{~g}$} & $101.13 \mathrm{~g}$ & $65.34 \mathrm{~g}$ \\
\hline Steel & \multicolumn{2}{|c|}{$19.61 \mathrm{~g}$} & $30.34 \mathrm{~g}$ & $19.60 \mathrm{~g}$ \\
\hline Antifouling & \multicolumn{2}{|c|}{$41.61 \mathrm{~g}$} & $64.37 \mathrm{~g}$ & $41.59 \mathrm{~g}$ \\
\hline Paint & \multicolumn{2}{|c|}{$10.47 \mathrm{~g}$} & $16.19 \mathrm{~g}$ & $10.46 \mathrm{~g}$ \\
\hline Lubricant oil & \multicolumn{2}{|c|}{$51.92 \mathrm{~g}$} & $80.33 \mathrm{~g}$ & $51.91 \mathrm{~g}$ \\
\hline Tap water & \multicolumn{2}{|c|}{$260.82 \mathrm{~kg}$} & $403.50 \mathrm{~kg}$ & $260.72 \mathrm{~kg}$ \\
\hline Polyethylene (LDPE) & \multicolumn{2}{|c|}{$32.23 \mathrm{~g}$} & $49.86 \mathrm{~g}$ & $32.22 \mathrm{~g}$ \\
\hline Nylon & \multicolumn{2}{|c|}{$17.75 \mathrm{~g}$} & $27.45 \mathrm{~g}$ & $17.74 \mathrm{~g}$ \\
\hline Tap water & \multicolumn{2}{|c|}{$1219.03 \mathrm{~kg}$} & $259.40 \mathrm{~kg}$ & $1218.58 \mathrm{~kg}$ \\
\hline Carbon dioxide & \multicolumn{2}{|c|}{0} & 0 & $45.15 \mathrm{~kg}$ \\
\hline Ethanol & \multicolumn{2}{|c|}{$39.64 \mathrm{~kg}$} & 0 & $106.70 \mathrm{~kg}$ \\
\hline Distilled water & \multicolumn{2}{|c|}{$644.58 \mathrm{~kg}$} & $288.217 \mathrm{~kg}$ & $646.23 \mathrm{~kg}$ \\
\hline Formaldehyde & \multicolumn{2}{|c|}{$1.43 \mathrm{~kg}$} & 0 & $1.43 \mathrm{~kg}$ \\
\hline Sulfuric acid & \multicolumn{2}{|c|}{$1.74 \mathrm{~kg}$} & 0 & $1.74 \mathrm{~kg}$ \\
\hline Disodium carbonate & \multicolumn{2}{|c|}{$1.75 \mathrm{~kg}$} & 0 & $1.75 \mathrm{~kg}$ \\
\hline Acetone & \multicolumn{2}{|c|}{$20.79 \mathrm{~kg}$} & 0 & $20.78 \mathrm{~kg}$ \\
\hline \multicolumn{5}{|l|}{ Energy } \\
\hline \multicolumn{5}{|l|}{ Diesel (associated with S1. } \\
\hline $\begin{array}{l}\text { Collection from natural } \\
\text { environment) }\end{array}$ & $23.25 \mathrm{~kg}$ & $23.25 \mathrm{~kg}$ & $35.97 \mathrm{~kg}$ & $23.24 \mathrm{~kg}$ \\
\hline $\begin{array}{l}\text { Electricity from the grid (used in all } \\
\text { the stages except for S1) }\end{array}$ & $1075.05 \mathrm{kWh}$ & $931.46 \mathrm{kWh}$ & $1586.00 \mathrm{kWh}$ & $3207.02 \mathrm{kWh}$ \\
\hline \multicolumn{5}{|c|}{$\begin{array}{ll}\text { INPUTS from ENVIRONMENT } \\
\end{array}$} \\
\hline \multicolumn{5}{|l|}{ Materials } \\
\hline Macroalgal biomass & \multicolumn{2}{|c|}{$3.11 \mathrm{~kg}_{\mathrm{DW}}$} & $4.81 \mathrm{~kg}_{\mathrm{DW}}$ & $3.11 \mathrm{~kg}_{\mathrm{DW}}$ \\
\hline Sand and residues & \multicolumn{2}{|c|}{$155.25 \mathrm{~g}$} & $240.18 \mathrm{~g}$ & $155.19 \mathrm{~g}$ \\
\hline Seawater & \multicolumn{2}{|c|}{$29.42 \mathrm{~kg}$} & $45.52 \mathrm{~kg}$ & $29.41 \mathrm{~kg}$ \\
\hline \multicolumn{5}{|c|}{ OUTPUTS to TECHNOSPHERE } \\
\hline \multicolumn{5}{|l|}{ Products } \\
\hline Fucoxanthin & \multicolumn{2}{|c|}{0} & 0 & $0.37 \mathrm{~g}$ \\
\hline Alginate & \multicolumn{2}{|c|}{$0.35 \mathrm{~kg}$} & 0 & $0.35 \mathrm{~kg}$ \\
\hline Antioxidant extract & 0.65 & $\mathrm{~kg}$ & $1.00 \mathrm{~kg}$ & $0.65 \mathrm{~kg}$ \\
\hline Avoided product ${ }^{1}$ & & & & \\
\hline $\begin{array}{l}\text { Nitrogen-rich fertilizer (expressed as } \\
\mathrm{kg} \mathrm{N} \text { ) }\end{array}$ & 8.10 & & $12.53 \mathrm{~g}$ & $8.10 \mathrm{~g}$ \\
\hline
\end{tabular}


Table 3. Global inventory table for the valorization of invasive macroalga $S$. muticum (FU: $1 \mathrm{~kg}$ valorized biomass)

(Cont.).

\begin{tabular}{|c|c|c|c|}
\hline & $\begin{array}{ll}\text { Sc 1. Alginate } & \text { Sc 2. Alginate } \\
+ \text { antioxidant } & + \text { antioxidant } \\
\text { extract from } & \text { extract from } \\
\text { dry alga } & \text { wet alga }\end{array}$ & $\begin{array}{l}\text { Sc } 3 \text {. } \\
\text { Antioxidant } \\
\text { extract from } \\
\text { wet alga }\end{array}$ & $\begin{array}{l}\text { Sc } 4 \text {. Fucoxanthin- } \\
\text { containing extract }+ \\
\text { alginate+ antioxidant } \\
\text { extract from freeze- } \\
\text { dried alga }\end{array}$ \\
\hline \multicolumn{4}{|c|}{ OUTPUTS to TECHNOSPHERE } \\
\hline \multicolumn{4}{|l|}{ Wastes to landfill } \\
\hline Polyester, to sanitary landfill & $65.37 \mathrm{~g}$ & $101.13 \mathrm{~g}$ & $65.34 \mathrm{~g}$ \\
\hline Steel, to inert landfill & $19.61 \mathrm{~g}$ & $30.34 \mathrm{~g}$ & $19.60 \mathrm{~g}$ \\
\hline Polyethylene, to sanitary landfill & $32.23 \mathrm{~g}$ & $49.86 \mathrm{~g}$ & $32.22 \mathrm{~g}$ \\
\hline Nylon, textiles to municipal incineration & $17.75 \mathrm{~g}$ & $27.45 \mathrm{~g}$ & $17.74 \mathrm{~g}$ \\
\hline \multicolumn{4}{|c|}{ OUTPUTS to ENVIRONMENT } \\
\hline \multicolumn{4}{|l|}{ Water emissions } \\
\hline Xylene & $3.71 \mathrm{~g}$ & $5.748 \mathrm{~g}$ & $3.71 \mathrm{~g}$ \\
\hline Cobalt & $1.59 \mathrm{mg}$ & $2.46 \mathrm{mg}$ & $1.59 \mathrm{mg}$ \\
\hline Copper & $8.62 \mathrm{~g}$ & $13.34 \mathrm{~g}$ & $8.62 \mathrm{~g}$ \\
\hline Zinc & $3.90 \mathrm{~g}$ & $6.03 \mathrm{~g}$ & $3.90 \mathrm{~g}$ \\
\hline Ethylbenzene & $0.97 \mathrm{~g}$ & $1.50 \mathrm{~g}$ & $0.97 \mathrm{~g}$ \\
\hline Sea nine 211 & $0.42 \mathrm{~g}$ & $0.64 \mathrm{~g}$ & $0.42 \mathrm{~g}$ \\
\hline 4-methylpentan-2-one & $0.42 \mathrm{~g}$ & $0.64 \mathrm{~g}$ & $0.42 \mathrm{~g}$ \\
\hline Wastewater & $2125.67 \mathrm{~kg}$ & $989.53 \mathrm{~kg}$ & $2126.75 \mathrm{~kg}$ \\
\hline Ethanol & $39.91 \mathrm{~kg}$ & 0 & $106.98 \mathrm{~kg}$ \\
\hline Formaldehyde & $1.43 \mathrm{~kg}$ & 0 & $1.43 \mathrm{~kg}$ \\
\hline Sulfuric acid & $1.74 \mathrm{~kg}$ & 0 & $1.74 \mathrm{~kg}$ \\
\hline Acetone & $20.79 \mathrm{~kg}$ & 0 & $20.78 \mathrm{~kg}$ \\
\hline Disodium carbonate & $1.75 \mathrm{~kg}$ & 0 & $1.75 \mathrm{~kg}$ \\
\hline \multicolumn{4}{|l|}{ Air emissions } \\
\hline Carbon dioxide & $73.65 \mathrm{~kg}$ & $113.94 \mathrm{~kg}$ & $73.62 \mathrm{~kg}$ \\
\hline Sulfur dioxide & $0.05 \mathrm{~kg}$ & $0.07 \mathrm{~kg}$ & $0.05 \mathrm{~kg}$ \\
\hline $\begin{array}{l}\text { Non-methane volatile organic compounds } \\
\text { (NMVOC) }\end{array}$ & $0.69 \mathrm{~kg}$ & $1.06 \mathrm{~kg}$ & $0.69 \mathrm{~kg}$ \\
\hline Methane & $4.19 \mathrm{~kg}$ & $6.47 \mathrm{~kg}$ & $4.18 \mathrm{~kg}$ \\
\hline Nitrogen oxides (NOx) & $0.55 \mathrm{~kg}$ & $0.84 \mathrm{~kg}$ & $0.55 \mathrm{~kg}$ \\
\hline Carbon monoxide & $0.17 \mathrm{~kg}$ & $0.27 \mathrm{~kg}$ & $0.17 \mathrm{~kg}$ \\
\hline Particulates & $0.04 \mathrm{~kg}$ & $0.07 \mathrm{~kg}$ & $0.04 \mathrm{~kg}$ \\
\hline Carbon dioxide & $73.65 \mathrm{~kg}$ & $113.94 \mathrm{~kg}$ & $118.79 \mathrm{~kg}$ \\
\hline
\end{tabular}

${ }^{\mathrm{T}} \mathrm{N}$ dosage is equivalent to $1.5 \%$ (dry weight) nitrogen content within biomass. Since $\mathrm{C} / \mathrm{N}$ ratio is higher than 25 , all present nitrogen can be absorbed by plants.

\subsection{Life cycle impact assessment}

Among the phases defined by LCA standard methodology (ISO 14040, 2006) only classification and characterization stages were undertaken, since normalization and weighting are 
optional (and, to some extent, subjective) elements that provide no additional information according to the goal and scope of the study.

Characterization factors reported by the Centre of Environmental Science of Leiden University (CML 2001 method) were applied (Guinée et al., 2002), and the potential impact categories analysed were: abiotic depletion (ADP), acidification (AP), eutrophication (EP), global warming (GWP), ozone layer depletion (ODP), human toxicity (HTP), freshwater aquatic ecotoxicity (FEP), marine aquatic ecotoxicity (MEP), terrestrial ecotoxicity (TEP) and photochemical oxidants formation (POFP).

\section{Results and discussion}

3.1 Comparative environmental performance of the valorization strategies of S. muticum biomass

LCA characterization results of the evaluated scenarios are summarized in Table $\mathbf{4}$ and calculated taken $1 \mathrm{~kg}$ of valorized biomass as reference. According to the results depicted in Figure 3, valorization by extracting sodium alginate and antioxidant fraction from wet algae would be the most appropriate route in terms of most impact categories. Thus, Sc 2 presents

contributions between $4 \%$ (for FEP) and 12\% (for EP, MEP or TEP) lower than the impacts of the base scenario Sc1. Moreover, the environmental profiles of strategies Sc 1 and Sc 2 are also better than the performance of Sc 3. Thus, the contributions when extracting only the antioxidant fraction are from $14 \%$ to $44 \%$ higher than those of Sc 1 and exceed the values of Sc 2 in a range of $26 \%$ up to $64 \%$, except for FEP that presents a contribution $52 \%$ lower than Sc 1 and $49 \%$ lower than Sc 2. Finally, Sc 4 was found as the alternative with the highest contributions in all 
the evaluated categories, being these contributions more than 1.5 times higher for FEP and nearly 3 times higher for HTP, MEP or TEP in comparison with the other three scenarios.

Table 4. Impact assessment results (characterization step) associated with $1 \mathrm{~kg}$ valorized Sargassum muticum in the four evaluated scenarios.

\begin{tabular}{|c|c|c|c|c|c|}
\hline \multirow{2}{*}{ Impact category } & \multirow{2}{*}{ Unit } & \multicolumn{4}{|c|}{ FU: 1 kg valorized Sargassum muticum } \\
\hline & & Sc 1 & Sc 2 & Sc 3 & Sc 4 \\
\hline Abiotic depletion (ADP) & $\mathrm{kg} \mathrm{Sb}$ eq & 6.73 & 6.11 & 7.70 & 17.54 \\
\hline Acidification (AP) & $\mathrm{kg} \mathrm{SO}_{2}$ eq & 8.13 & 7.31 & 9.75 & 20.58 \\
\hline Eutrophication (EP) & $\mathrm{kg} \mathrm{PO}_{4}{ }^{-3}$ eq & 1.43 & 1.27 & 1.97 & 4.05 \\
\hline Global warming (GWP) & $\mathrm{kg} \mathrm{CO} \mathrm{CO}_{2}$ & 917.47 & 832.56 & 1220.82 & 2341.76 \\
\hline Ozone layer depletion (ODP) & $\mathrm{mg} \mathrm{CFC}-11_{\mathrm{eq}}$ & 47.40 & 42.82 & 67.52 & 120.03 \\
\hline Human toxicity (HTP) & $\begin{array}{l}\mathrm{kg} \text { 1,4-dichlorobenzene } \\
\qquad\left(\mathrm{DB}_{\mathrm{eq}}\right)\end{array}$ & 197.12 & 173.14 & 274.74 & 602.29 \\
\hline $\begin{array}{l}\text { Freshwater aquatic ecotoxicity } \\
\text { (FEP) }\end{array}$ & $\mathrm{kg} 1,4-\mathrm{DB}_{\mathrm{eq}}$ & 605.06 & 578.95 & 292.88 & 1007.06 \\
\hline Marine aquatic ecotoxicity (MEP) & $\mathrm{kg} 1,4-\mathrm{DB}_{\mathrm{eq}}$ & 131.14 & 114.61 & 188.37 & 385.95 \\
\hline $\begin{array}{l}\text { Terrestrial aquatic ecotoxicity } \\
\text { (TEP) }\end{array}$ & g $1,4-\mathrm{DB}_{\mathrm{eq}}$ & 45.23 & 39.84 & 61.61 & 128.10 \\
\hline $\begin{array}{l}\text { Photochemical oxidants formation } \\
\text { (POFP) }\end{array}$ & $\mathrm{g} \mathrm{C}_{2} \mathrm{H}_{4}$ eq & 333.42 & 303.55 & 392.28 & 880.84 \\
\hline
\end{tabular}

Sc 1. Alginate + antioxidant extract from dry alga

Sc 2. Alginate + antioxidant extract from wet alga

Sc 3. Antioxidant extract from wet alga

Sc 4. Fucoxanthin-containing extract + alginate + antioxidant extract from freeze-dry alga 


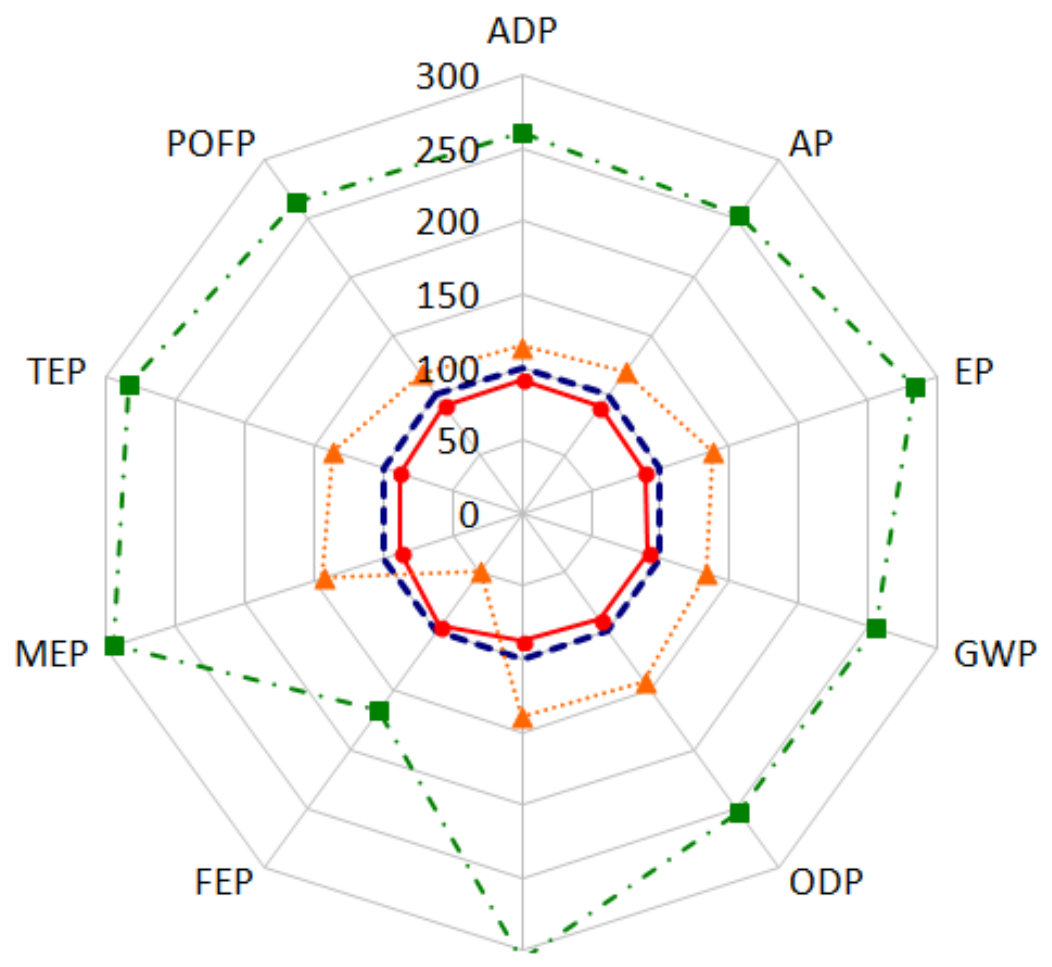

HTP

- - Sc 1. Dry alga to alginate + antioxidant

$\longrightarrow$ Sc 2 . Wet alga to alginate + antioxidant

$\cdots$..... Sc 3. Wet alga to antioxidant

- E- Sc 4. Freeze-dried alga to fucoxanthin + alginate + antioxidant

Figure 3. Relative environmental profile of the compared valorization scenarios with $\mathrm{Sc} 1$ being the baseline (index=100) when considering $1 \mathrm{~kg}$ valorized alga as functional unit.

\subsection{Identification of hot spots for the valorization strategies of S. muticum biomass}

Figure 4 depicts the most problematic subsystems contributing to the environmental impacts of the four valorization alternatives. In the case of Sc 1, the non-isothermal hydrolysis (S6) is the major contributor to most impact categories that accounts from $45 \%$ up to $60 \%$, except for FEP, which is dominated by the extraction of alginate from the algal biomass (S4) with $70 \%$ of the contribution. S4 also has a significant effect in terms of AP (21\%). Among the secondary stages, the pretreatment of algal biomass for extraction (S2) has remarkable contributions, especially in 
EP (21\%), HTP (22\%), MEP (23\%) and TEP (22\%). The collection of algae from natural environment (S1) is responsible for $20 \%$ of impact to GWP and nearly $23 \%$ ODP, whereas the precipitation of alginate (S5) has rather limited effects in most categories, despite being the second cause of ADP (22\%) and POFP (20\%).

\section{Contributions per subsystem}

Sc 1

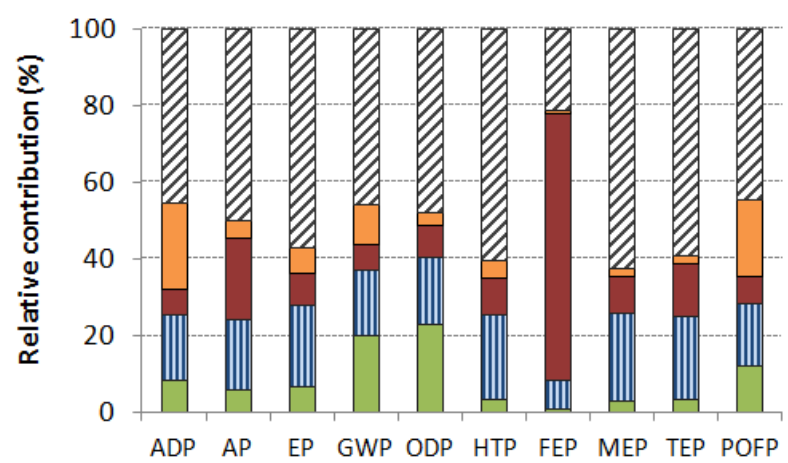

Sc 3

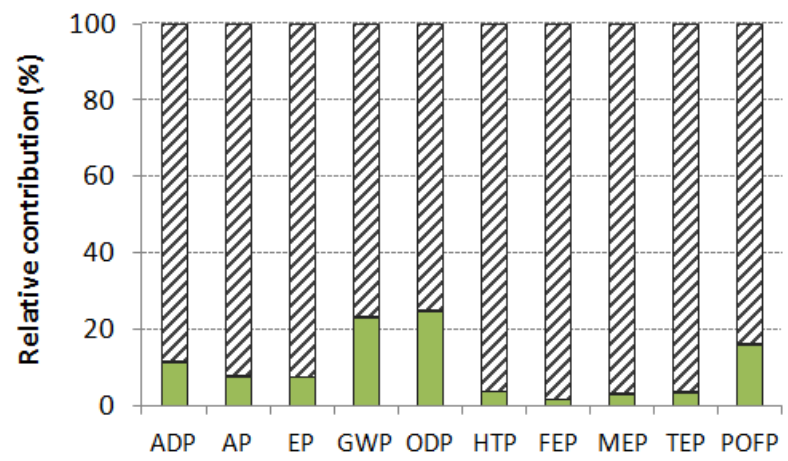

$\square$ S1. Collection from environment

… S3. Supercritical extraction of fucoxanthin-containing extract

$\square$ S5. Precipitation of alginate
Sc 2

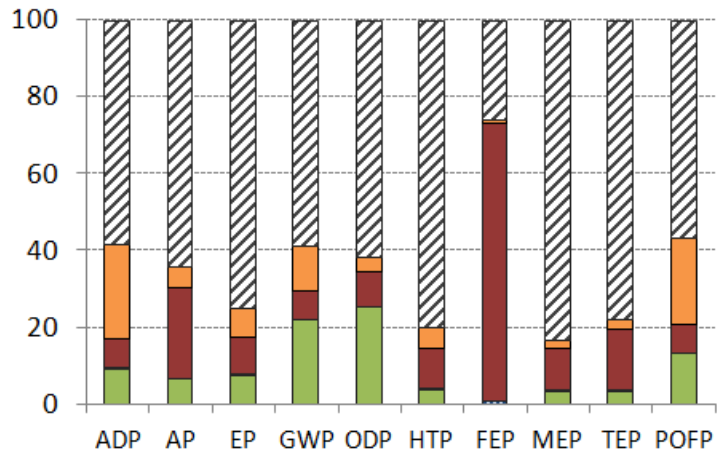

Sc 4

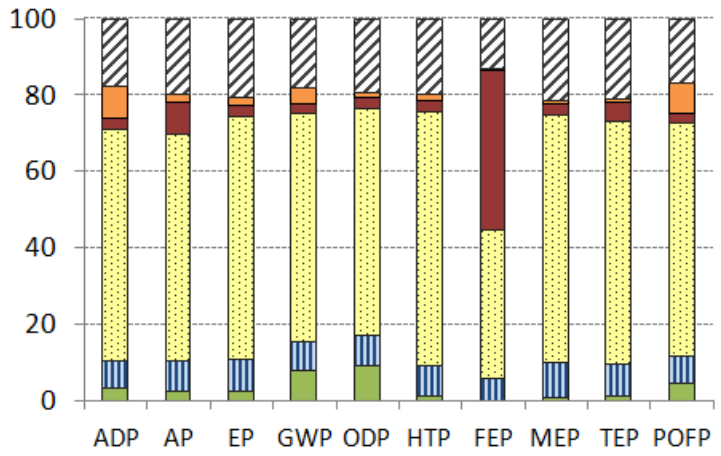

m S2. Pretreatment for extraction

$\square$ S4. Extraction of alginate

\66. Non-isothermal autohydrolysis

Figure 4. Relative contributions per subsystem to the environmental profile of the compared scenarios for $1 \mathrm{~kg}$ valorized alga as functional unit.

Regarding the activities associated with these impacts, shown in Figure 5, electricity is clearly the hot spot in Sc 1. This activity exhibits a global contribution ranging from $67 \%$ to $95 \%$ of the total impacts in all the categories except for FEP, which presents $66 \%$ of the impact related 
to waste streams (specifically linked to organic solvent emissions to water in S4). The highest electricity consumption (66\% of total electricity) corresponds to S6 that has three energyintensive steps with significant electricity requirements (drying, autohydrolysis in reactor itself and, to a larger extent, freeze-drying of the obtained extract), followed by S2 (24\% of total electricity) mainly due to drying step for the preparation of the algae for extraction. Among the secondary processes, the production of chemicals constitutes a major contributor in terms of $\operatorname{ADP}(23 \%)$ and POFP $(21 \%)$ related to the production of ethanol and, to a lesser extent, acetone, both required for the precipitation of alginate in S5. Vessel operations cause $20 \%$ of the total impact in GWP and $23 \%$ of ODP, especially due to the consumption of diesel and the derived greenhouse gas emissions. Although the use of residual biomass as a fertilizer represents a reduction of impact (avoided synthetic fertilizer), the limited amount of material results in a negligible improvement, much lower than $1 \%$ of the total impacts in all the categories.

When it comes to Sc 2, the effect of S2 is remarkably lower than for Sc 1, falling from contributions between $16 \%$ and $23 \%$ in most categories to less than $0.5 \%$. This change is due to the omission of the drying stage (resulting in a remarkable reduction in electricity consumption) that was proven to be feasible without affecting the extraction stages and yields in scenarios where only alginate and antioxidant extract were obtained. Therefore, S6 dominates the environmental burdens (between $57 \%$ and $83 \%$ depending on the category) except for contributions to FEP, which are again associated with S4 (73\% of total FEP). As in the previous case, S5 is only relevant for ADP (24\%) and POFP (22\%), whereas S1 affects GWP and ODP in $22 \%$ and $25 \%$ respectively. Concerning the production processes that are associated with the subsystems, the production of electricity to meet the energy requirements is again the hot spot with contributions that range between $64 \%$ and $94 \%$ to all the categories excluding FEP (69\% 
from waste treatment processes), despite the slight decrease of the influence of electricity with respect to Sc 1 . Nearly $90 \%$ of this electricity consumption is related to S6, due to the combined requirements associated with the steps of drying, autohydrolysis and mostly freeze-drying. Following the same trend as Sc 1, vessel operations are responsible for the second highest contributions to GWP (22\%) and ODP (25\%), while the production of chemicals only affects $\operatorname{ADP}(25 \%)$ and POFP (23\%).

\section{Contributions per involved activity}
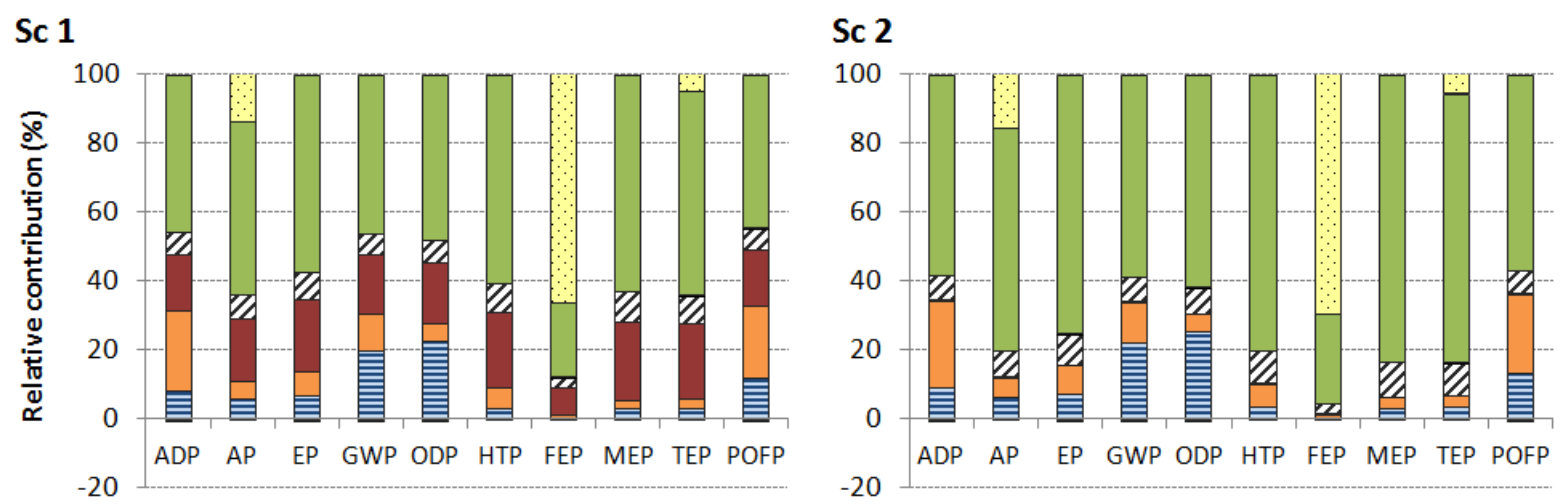

Sc 3

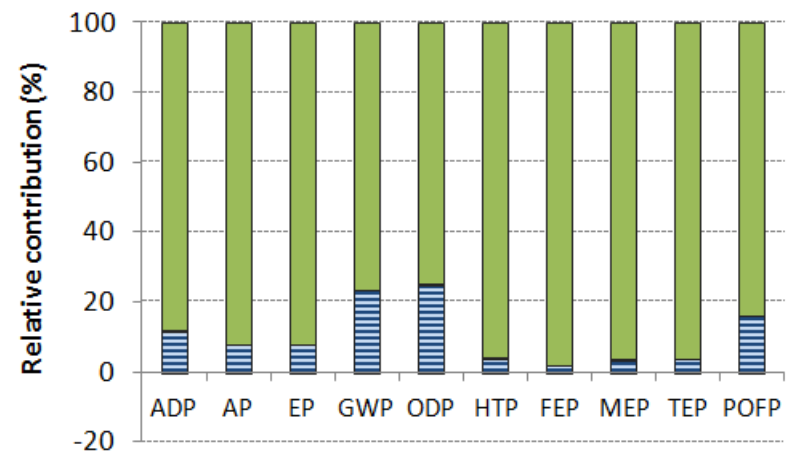

Sc 4

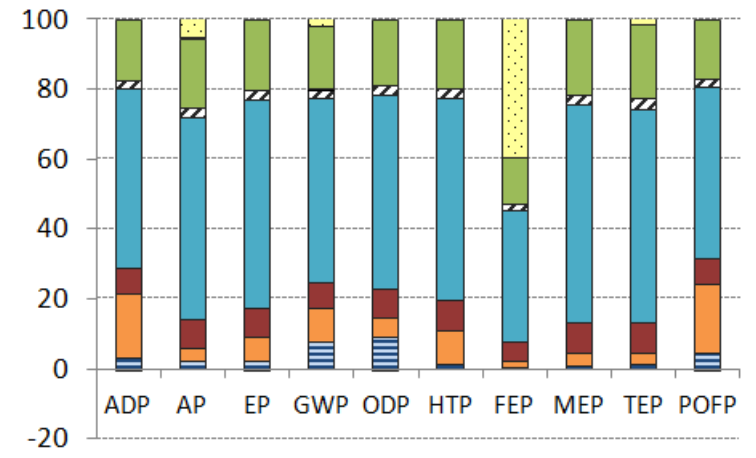

目 Vessel operations

Electricity for biomass pretreatment

$\square$ Chemicals \& water

Electricity for extraction of alginate

$\square$ Electricity for extraction of fucoxanthin-containing extract Electricity for precipitation of alginate

$\square$ Electricity for non-isothermal autohydrolysis

圈 Waste treatment

Figure 5. Relative contributions per involved activity to the environmental profile of the compared scenarios for 1 $\mathrm{kg}$ valorized alga as functional unit. 
In the case of Sc 3, due to the elimination of S4 and S5, the contributions of S1 and S6 exhibit a noticeable increase in relative terms. S6 clearly constitutes the hot spot in all the evaluated categories, ranging from $75 \%$ to $98 \%$ of the impact depending on the category. S1 mainly affects GWP (23\%) and ODP (25\%). Regarding the involved activities, the contributions related to electricity are responsible for more than $75 \%$ of the impact to all categories, with $99 \%$ of these requirements coming from S6. Another significant change in this scenario is the sharp decrease of the impacts from waste treatment (from around $70 \%$ in Sc 1 and Sc 2 to $0.3 \%$ in Sc 3). This is due to the fact that no organic solvents are emitted to water when the extraction of alginate is not performed.

Finally, the environmental profile of Sc 4 is remarkably different compared with the other three situations as a result of the implementation of a supercritical extraction stage to obtain fucoxanthin-containing extract. In this case, S3 is certainly the major hot spot in all the impact categories with contributions between $39 \%$ and 66\%. Among the other subsystems, S6 has significant effects in all categories (between 13\% and 22\%) and S4 only affects noticeably FEP (42\%), while all the other contributions are below $10 \%$. The main reason for this behavior is the need for electricity to satisfy the high energy requirements of the supercritical extraction that affect the impact categories between $38 \%$ and $62 \%$. This consumption corresponds to $65 \%$ of the total electricity required, whereas more than $22 \%$ of the remaining demand is related to S6 and 9\% is due to the freeze-drying of biomass in $\mathrm{S} 2$ that is necessary to perform the supercritical extraction. Among the processes that are not related to electricity, only three contributions exceed $10 \%$ of the impacts: the production of chemicals for ADP (18\%) and POFP (20\%), jointly with waste flows for FEP (40\%). 


\subsection{Sensitivity assessment of the model}

The comparative analysis conducted in this study shows up the great influence of the extraction pathway in the LCA results. Although no similar works related to valuable compounds obtained from macroalgae have been found in the literature, the identification of hot spots is consistent with previous findings related to the important effect of electricity requirements in harvesting and extraction processes associated with other products from marine organisms, such as lipid extraction from microalgae or biofuels from macroalgae (Aresta et al., 2005; Beach et al., 2012). Indeed, a 10\% reduction in electricity requirements could lead to improvements between 3\% and 10\% of the total impacts depending on the considered category (Supplementary information, Fig. S1).

In addition to the impact associated with the production of electricity, organic solvents can also result in a significant contribution that in this case was observed when considering the precipitation of alginate. With this regard, Raymond et al. (2010) found that the possibility of solvent recovery or reduction could entail up to $90 \%$ of reduction in overall emissions. In this case, ethanol associated with alginate precipitation was the main contribution among the chemicals. As a recovery system was already taken into account or the base inventory, a comparison of the assessed scenarios with and without ethanol recovery was conducted (Supplementary information, Fig. S2). According to the results, solvent recovery is a key issue in the three scenarios that include the precipitation of alginate (Sc 1, Sc 2 and Sc 4). The omission of this system would cause a remarkable increase in the environmental impacts related to most categories, especially ADP and POPF, which exceed the original value in $25 \%$ for Sc 4 and nearly double their contributions when considering Sc 1 and Sc 2 . 


\subsubsection{Effect of changes in biomass composition}

The environmental results analyzed in the previous sections were calculated for the case in which the antioxidant extract contained the highest concentration of fucoidans (final temperature of $170^{\circ} \mathrm{C}$ during non-isothermal autohydrolysis). However, González-López et al. (2012) found a remarkable influence of the final heating temperature on the solubilization of solids and therefore, on the final amount of antioxidant extract obtained. As the antioxidant fraction constitutes the main product as much in mass as in economic terms, a change in the obtained amount may significantly affect the global environmental profile of the process. Moreover, the considered quantity of extracted fucoxanthin (12 mg fucoxanthin/100 g dry algae) corresponds to the maximum experimental yield obtained, although $\mathrm{S}$. muticum contains up to $55.1 \mathrm{mg} / 100 \mathrm{~g}$ dry algae (Conde et al., 2012). Additionally, seasonal variations may also result in important changes in the composition of the biomass, and therefore in the product distribution (Balboa et al., 2013).

For this reason, a sensitivity assessment was conducted. The potential impacts for all the scenarios were calculated in two opposite situations: the maximization of the amount of antioxidant extract (autohydrolysis temperature of $200^{\circ} \mathrm{C}$ to obtain $41 \%$ dry algae as antioxidant extract) and the operation with minimum amount of antioxidant extract (temperature of $150^{\circ} \mathrm{C}$ to obtain $13 \%$ dry algae as antioxidant extract). For Sc 4, an additional situation was evaluated, considering the highest content of fucoxanthin in the biomass: $55.1 \mathrm{mg} / 100 \mathrm{~g}$ algae (Supplementary information, Tables S2-S5). The results reveal the clear dependence of the environmental performance on the operational conditions of S6. Thus, a change of $17 \%$ in the final temperature for the non-isothermal autohydrolysis (from 170 to $200^{\circ} \mathrm{C}$ ) turns into a reduction of impact around 33\% for Sc 1 and Sc 2, 44\% for Sc 3 and 37\% for Sc 4, whereas 
lowering temperature by $12 \%$ (from 170 to $150^{\circ} \mathrm{C}$ ) involves increases from $25 \%$ (for Sc 1 , Sc 2 and Sc 4) up to $50 \%$ for Sc 3. Concerning Sc 4, the increment in the recovered amount of fucoxanthin has virtually no effect in the environmental profile.

\subsubsection{Effect of FU choice in the environmental profiles}

The results from Sections 3.1 and 3.2 show that Sc 4 presents much higher environmental burdens than the other three alternatives. However, it should be pointed out that in this scenario an additional valuable compound is obtained. Fucoxanthin is a biologically active molecule with a high value, not only in economic terms, but also with potential uses in the pharmaceutical sector. Moreover, Sc 3 has higher environmental impacts than Sc 1 and Sc 2 in most categories per $\mathrm{kg}$ valorized biomass, but the obtained product (1 $\mathrm{kg}$ antioxidant extract) is significantly more valuable than the product of Sc 1 and $\mathrm{Sc} 2(0.65 \mathrm{~kg}$ antioxidant extract and $0.35 \mathrm{~kg}$ alginate).

The obtained results are based on a FU that focuses on the amount of valorized biomass rather than on the obtained products. Indeed, the choice of the FU is a critical point in a LCA study and several authors consider it as a limitation since it is a subjective matter (Fleischer and Schmidt, 1996; Schau and Fet, 2008). The influence of the FU is particularly important when using LCA as a decision tool, so special attention must be paid to select an appropriate FU with an equivalent function in all the compared systems (Schau and Fet, 2008). The selected FU considers the maximization of valorized biomass as the main function of the system but does not include the benefits of the process associated with the production of valuable molecules.

Hence, a second approach is presented below, consisting of a FU focused on the products obtained instead of the amount of biomass processed. High-purity fucoxanthin has a market value of up to $9000 € / \mathrm{g}$, although the fucoxanthin-containing extract that is obtained in this case 
has a significantly lower price ranging between $40-240 € / g$. The value of the antioxidant extract is estimated around $170 € / \mathrm{g}$ (according to the price of similar extracts from other macroalgae) and that of sodium alginate is lower than $0.10 € / g$ (www.sigmaaldrich.com). Considering that the antioxidant extract and the alginate were the major components in quantitative terms and the antioxidant extract (obtained in all configurations) had a much higher value, the FU was selected as $1 \mathrm{~kg}$ of antioxidant extract. Since two additional co-products (fucoxanthin-containing extract and alginate) were obtained, economic allocation was applied according to the Handbook on Life Cycle Assessment (Guinée et al., 2002) and economic values of the three products were used for allocation. However, not all the subsystems were associated with the three products (e.g. supercritical extraction -S3- was only related to fucoxanthin), so allocation factors varied within the subsystems of each evaluated scenario. A summary of the considered allocation factors is given in Table 5.

The effect of this alternative FU in the environmental profiles is shown in Table 6 and Figure 6. According to the considered economic allocation, the results change significantly with respect to the previous analysis. Thus, Sc 4 is not the alternative with the highest impacts and Sc 3 constitutes the least appealing option. However, the differences between scenarios 1, 3 and 4 are lower than $5 \%$ in all categories. The integral valorization of biomass by extracting the three high value compounds becomes competitive when considering the product-based FU with economic allocation. Again, Sc 2 is the preferred scenario according to the environmental performance and has contributions between $10 \%$ and 15\% lower than Sc 1. The most relevant reductions of impact are linked to toxicity categories, because no solvents are needed to obtain the antioxidant extract. 
Table 5. Partitioning fraction for economic allocation in the evaluated scenarios for $1 \mathrm{~kg}$ of antioxidant extract.

\begin{tabular}{|c|c|c|c|c|c|c|c|c|}
\hline & & $\begin{array}{c}\mathbf{g} \\
\text { product/kg } \\
\text { valorized } \\
\text { alga }\end{array}$ & Stage 1 & Stage 2 & Stage 3 & Stage 4 & Stage 5 & Stage 6 \\
\hline \multirow[t]{3}{*}{$\begin{array}{l}\text { Sc } 1 \\
\text { and } \\
\text { Se } 2\end{array}$} & $\begin{array}{l}\text { Fucoxanthin- } \\
\text { containing } \\
\text { extract }\end{array}$ & 0 & $0.00 \%$ & $0.00 \%$ & $0.00 \%$ & $0.00 \%$ & $0.00 \%$ & $0.00 \%$ \\
\hline & Alginate & 353.61 & $0.03 \%$ & $0.03 \%$ & $0.03 \%$ & $100.00 \%$ & $100.00 \%$ & $0.00 \%$ \\
\hline & $\begin{array}{l}\text { Antioxidant } \\
\text { extract }\end{array}$ & 646.39 & $99.97 \%$ & $99.97 \%$ & $99.97 \%$ & $0.00 \%$ & $0.00 \%$ & $100.00 \%$ \\
\hline \multirow[t]{3}{*}{ Sc 3} & $\begin{array}{l}\text { Fucoxanthin- } \\
\text { containing } \\
\text { extract }\end{array}$ & 0 & $0.00 \%$ & $0.00 \%$ & $0.00 \%$ & $0.00 \%$ & $0.00 \%$ & $0.00 \%$ \\
\hline & Alginate & 0 & $0.00 \%$ & $0.00 \%$ & $0.00 \%$ & $0.00 \%$ & $0.00 \%$ & $0.00 \%$ \\
\hline & $\begin{array}{l}\text { Antioxidant } \\
\text { extract }\end{array}$ & 1000.00 & $100.00 \%$ & $100.00 \%$ & $100.00 \%$ & $100.00 \%$ & $100.00 \%$ & $100.00 \%$ \\
\hline \multirow[t]{3}{*}{ Sc 4} & $\begin{array}{l}\text { Fucoxanthin- } \\
\text { containing } \\
\text { extract }\end{array}$ & 0.37 & $0.05 \%$ & $0.05 \%$ & $100.00 \%$ & $0.00 \%$ & $0.00 \%$ & $0.00 \%$ \\
\hline & Alginate & 353.48 & $0.03 \%$ & $0.03 \%$ & $0.00 \%$ & $100.00 \%$ & $100.00 \%$ & $0.00 \%$ \\
\hline & $\begin{array}{l}\text { Antioxidant } \\
\text { extract }\end{array}$ & 646.15 & $99.93 \%$ & $99.93 \%$ & $0.00 \%$ & $0.00 \%$ & $0.00 \%$ & $100.00 \%$ \\
\hline
\end{tabular}


Table 6. Impact assessment results (characterization step) associated with $1 \mathrm{~kg}$ antioxidant extract and two economic allocation approaches in the four evaluated scenarios.

\begin{tabular}{|c|c|c|c|c|c|c|c|c|c|}
\hline \multirow{2}{*}{ Impact category } & \multirow{2}{*}{ Unit } & \multicolumn{4}{|c|}{ FU: 1 kg antioxidant extract, approach a } & \multicolumn{4}{|c|}{ FU: 1 kg antioxidant extract, approach b } \\
\hline & & Sc 1 & Sc 2 & Sc 3 & Sc 4 & Sc 1 & Sc 2 & Sc 3 & Sc 4 \\
\hline Abiotic depletion (ADP) & $\mathrm{kg} \mathrm{Sb}$ eq & 7.36 & 6.41 & 7.70 & 7.66 & 8.09 & 7.14 & 7.70 & 8.39 \\
\hline Acidification (AP) & $\mathrm{kg} \mathrm{SO}_{2} \mathrm{eq}$ & 9.31 & 8.05 & 9.75 & 9.70 & 11.99 & 10.73 & 9.75 & 12.34 \\
\hline Eutrophication (EP) & $\mathrm{kg} \mathrm{PO}_{4}^{-3}$ eq & 1.88 & 1.63 & 1.97 & 1.96 & 2.07 & 1.82 & 1.97 & 2.15 \\
\hline Global warming (GWP) & $\mathrm{kg} \mathrm{CO}_{2}$ eq & 1174.86 & 1043.56 & 1220.82 & 1215.54 & 1271.19 & 1139.89 & 1220.82 & 1311.54 \\
\hline Ozone layer depletion (ODP) & $\mathrm{mg} \mathrm{CFC}-11_{\mathrm{eq}}$ & 64.98 & 57.89 & 67.52 & 67.18 & 71.00 & 63.91 & 67.52 & 73.17 \\
\hline Human toxicity (HTP) & $\begin{array}{l}\mathrm{kg} \text { 1,4-dichlorobenzene } \\
\qquad\left(\mathrm{DB}_{\mathrm{eq}}\right)\end{array}$ & 261.77 & 224.70 & 274.74 & 273.29 & 290.58 & 253.50 & 274.74 & 301.69 \\
\hline Freshwater aquatic ecotoxicity (FEP) & $\mathrm{kg} 1,4-\mathrm{DB}_{\mathrm{eq}}$ & 278.75 & 238.38 & 292.88 & 291.19 & 929.29 & 888.92 & 292.88 & 941.56 \\
\hline Marine aquatic ecotoxicity (MEP) & $\mathrm{kg} 1,4-\mathrm{DB}_{\mathrm{eq}}$ & 179.43 & 153.88 & 188.37 & 187.32 & 198.64 & 173.09 & 188.37 & 206.42 \\
\hline Terrestrial aquatic ecotoxicity (TEP) & $\mathrm{g} 1,4-\mathrm{DB}_{\mathrm{eq}}$ & 58.69 & 50.36 & 61.61 & 61.28 & 68.40 & 60.07 & 61.61 & 70.96 \\
\hline $\begin{array}{l}\text { Photochemical oxidants formation } \\
\text { (POFP) }\end{array}$ & $\mathrm{g} \mathrm{C}_{2} \mathrm{H}_{4}$ eq & 376.13 & 329.94 & 392.28 & 390.46 & 410.72 & 364.53 & 392.28 & 423.35 \\
\hline
\end{tabular}

Sc 1. Alginate + antioxidant extract from dry alga

Sc 2. Alginate + antioxidant extract from wet alga

Sc 3. Antioxidant extract from wet alga

Sc 4. Fucoxanthin-containing extract + alginate + antioxidant extract from freeze-dry alga 

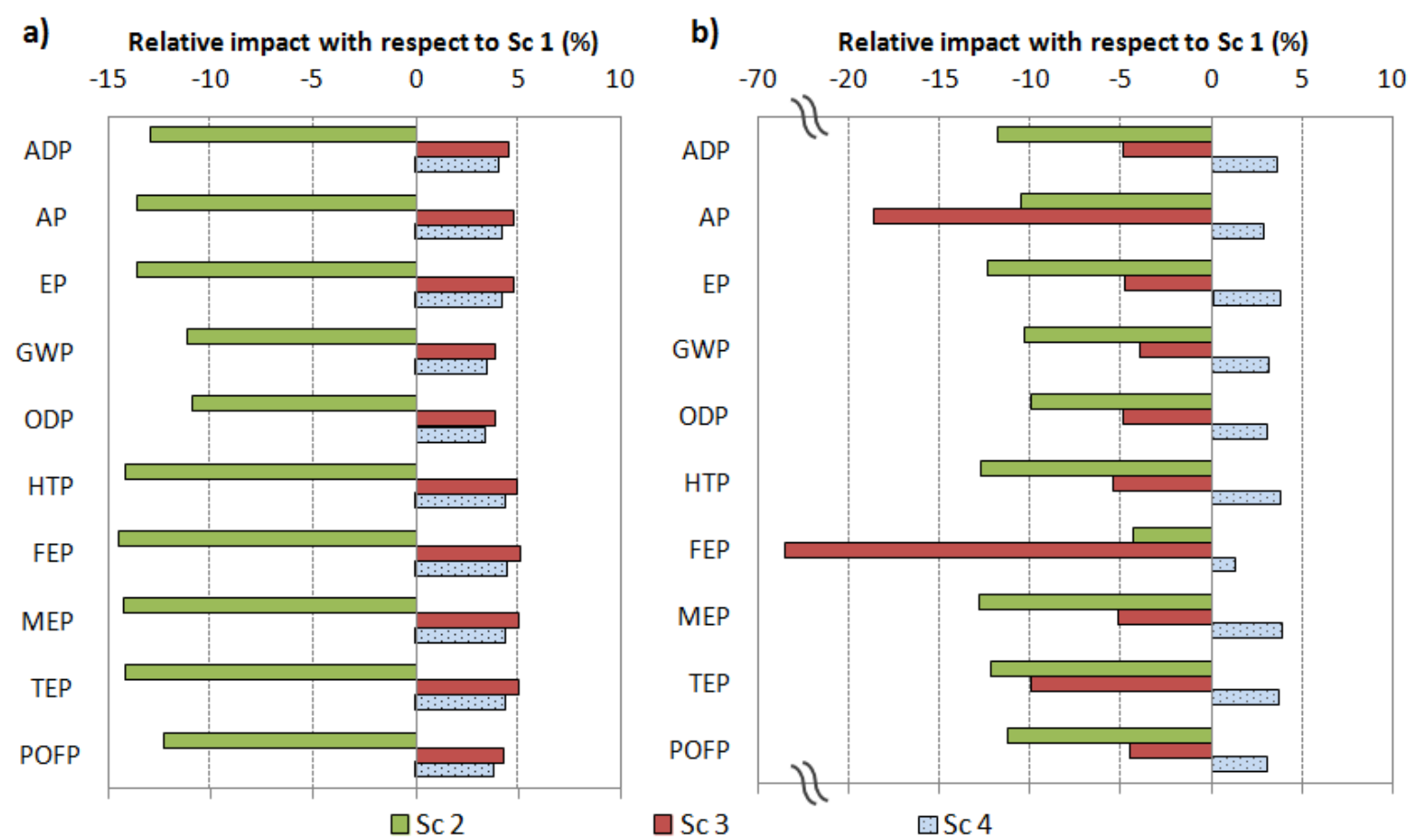

Figure 6. Relative environmental profile of Sc 2, Sc 3 and Sc 4 with respect to Sc 1 for $1 \mathrm{~kg}$ antioxidant extract as functional unit, with a) economic allocation considering null impact of antioxidant extract related to S4 and S5, and b) economic allocation considering benefits of S4 for antioxidant extraction due to biomass reduction.

These results are based on an economic allocation (a) that assigns a factor of 0 for the impact of the antioxidant extract related to S4 and S5, since these stages are not strictly necessary for obtaining the product. Nevertheless, the performance of stage S4 facilitates the non-isothermal autohydrolysis and allows reducing mass and energy consumptions in S6 due to the lower quantity of biomass treated. Therefore, a second allocation approach (b) was also assessed, allocating a fraction of the environmental main responsible for most impacts due, to a large extent, to the consumption of electricity in this stage. S2 has significant contributions in some specific categories, especially those related to toxicity, whereas the effect of S1 is limited to the categories of GWP, ODP and POFP, associated with vessel operations. S5 constitutes the main change with respect to the FU based on the valorized biomass, as it has no contribution to the 
impacts related to the antioxidant extract. S4 follows the same trend as S5 when considering approach a, although the behavior of this stage in economic allocation $\mathrm{b}$ is similar to the results of Section 3.2. Thus, in approach b S4 is the main responsible for impacts to FEP due to waste treatment associated with solvent residues.

\section{Conclusions}

The development of novel processes to valorize natural resources requires objective supporting tools to evaluate the efficiency of available technologies and identify the most suitable options from environmental, economic and social perspectives. Thus, the integral valorization of biomass, which was initially considered the most attractive scenario, is not necessarily a convenient approach. The results of this paper highlight the usefulness of LCA methodology as a decision-making tool, especially in processes under development related to emergent sectors such as marine biotechnology. The outcomes should be considered in order to improve current extraction techniques towards the optimal valorization of natural resources.

Acknowledgements This project has been developed within the framework of the BAMMBO Project (Project reference: FP7 KBBE-2010-4). The authors P. Pérez-López, S. González-García, G. Feijoo and M.T. Moreira belong to the Galician Competitive Research Group GRC 2013-032. P. Pérez-López would like to express her gratitude to the Spanish Ministry of Education for awarding a research fellowship (AP2012-1605). E. M. Balboa also thanks the Spanish MEC for her FPI grant (BES-2010-041807). Furthermore, the authors would like to thank Mr. Manuel Loureiro Pérez, managing director at Conservas y Ahumados Lou S.L. (www.conservaslou.com/index.php), for the data provided concerning the collection of algae. 


\section{Appendix A. Supplementary data}

Supplementary data associated with this article can be found, in the online version, at http://dx.doi.org/10.1016/j.biortech.2014.03.013.

\section{References}

Althaus, H.J., Chudacoff, M., Hischier, R., Jungbluth, N., Osses, M., Primas, A., 2007. Life Cycle Inventories of chemicals. Ecoinvent Report No. 8, v2.0. EMPA, Swiss Centre for Life Cycle Inventories, Dübendorf (Switzerland).

Alvarado-Morales, M., Boldrin, A., Karakashev, D.B., Holdt, S.L., Angelidaki, I., Astrup, T., 2013. Life cycle assessment of biofuel production from brown seaweed in Nordic conditions. Bioresour. Technol. 129, 92-99.

Anderson, L.W.J., 2007. Control of invasive seaweeds. Bot. Mar. 50 (5-6), 418-437.

Aresta, M., Dibenedetto, A., Barberio, G., 2005. Utilization of macro-algae for enhanced CO2 fixation and biofuels production: Development of a computing software for an LCA study. Fuel Process. Technol. 86 (14-15), 1679-1693.

Balboa, E.M., Conde, E., Moure, A., Falqué, E., Domínguez, H., 2013. In vitro antioxidant properties of crude extracts and compounds from brown algae. Food Chem. 138 (2-3), 17641785.

Beach, E.S., Eckelman, M.J., Cui, Z., Brentner, L., Zimmerman, J.B., 2012. Preferential technological and life cycle environmental performance of chitosan flocculation for harvesting of the algae Neochloris oleabundans. Bioresour. Technol. 121, 445-449.

Britton-Simmons, K.H., 2004. Direct and indirect effects of the introduced alga Sargassum muticum on benthic, subtidal communities of Washington State, USA. Mar. Ecol. Prog. Ser. 277, 61-78. 
Classen, M., Althaus, H.J., Blaser, S., Tuchschmid, M., Jungbluth, N., Doka, G., Faist Emmenegger, M., Scharnhorst, W., 2007. Life Cycle Inventories of metals. Ecoinvent Report No. 10, v2.0. EMPA, Swiss Centre for Life Cycle Inventories, Dübendorf (Switzerland).

Conde, E., Díaz Reinoso, B., Román-Figueroa, C., Balboa, E. M., Moure, A., Domínguez, H., Chamy, R., Parajó, J. C. 2012. Supercritical CO2 extraction of fucoxanthin from Sargassum muticum. 10th International Symposium on Supercritical Fluids, San Francisco. CA, USA.

Davis, T., Ramirez, M., Mucci, A., Larsen, B., 2004. Extraction, isolation and cadmium binding of alginate from Sargassum spp. J. Appl. Phycol. 16 (4), 275-284.

Doka, G., 2007. Life Cycle Inventories of waste treatment services. Ecoinvent Report No. 13, v2.0. EMPA, Swiss Centre for Life Cycle Inventories, Dübendorf (Switzerland).

Dones, R., Bauer, C., Bolliger, R., Burger, B., Faist Emmenegger, M., Frischknecht, R., et al., 2007. Life Cycle Inventories of energy systems: Results for current systems in Switzerland and other UCTE countries. Ecoinvent Report No. 5, v2.0. Paul Scherrer Institut Villigen, Swiss Centre for Life Cycle Inventories, Dübendorf (Switzerland).

Fleischer, G., Schmidt, W.P., 1996. Functional unit for systems using natural raw materials. Int. J. Life Cycle Assess. 1 (1), 23-27.

García-Salas, P., Morales-Soto, A., Segura-Carretero, A., Fernández-Gutiérrez, A., 2010. Phenolic-compound-extraction systems for fruit and vegetable samples. Molecules 15 (12), 8813-8826.

González-López, N., Moure, A., Domínguez, H., 2012. Hydrothermal fractionation of Sargassum muticum biomass. J. Appl. Phycol. 24 (6), 1569-1578.

Guinée, J.B., Gorrée, M., Heijungs, R., Huppes, G., Kleijn, R., de Koning, A., van Oers, L., Wegener, A., Suh, S., Udo de Haes, H.A., de Bruijn, H., van Duin, R., 2002. Handbook on 
Life Cycle Assessment: Operational guide to the ISO standards. Kluwer Academic Publishers, Dordrecht (The Netherlands).

Hischier, R., 2007. Life Cycle Inventories of packagings and graphical papers. Ecoinvent Report No. 11, v2.0. EMPA, Swiss Centre for Life Cycle Inventories, Dübendorf (Switzerland).

Hospido, A., Tyedmers, P., 2005. Life cycle environmental impacts of Spanish tuna fisheries. Fish. Res. 76 (2), 174-186.

ISO 14040. 2006. Environmental management - Life Cycle Assessment - Principles and framework, Geneva, Switzerland.

Jungbluth, N. Erdöl, 2007. Sachbilanzen von Energiesystemen: Grundlagen für den ökologischen Vergleich von Energiesystemen und den Einbezug von Energiesystemen in Ökobilanzen für die Schweiz. Ecoinvent report No. 6-IV, v2.0. Paul Scherrer Institut Villigen, Swiss Centre for Life Cycle Inventories, Dübendorf (Switzerland).

Kadam, S.U., Tiwari, B.K., O’Donnell, C.P., 2013. Application of novel extraction technologies for bioactives from marine algae. J. Agric. Food Chem. 61 (20), 4667-4675.

Kellenberger, D., Althaus, H.J., Jungbluth, N., Künniger, T., Lehmann, M., Thalmann, P., 2007. Life Cycle Inventories of building products. Ecoinvent Report No. 7, v2.0. EMPA, Swiss Centre for Life Cycle Inventories, Dübendorf (Switzerland).

Kraan, S., 2008. Sargassum muticum (Yendo) Fensholt in Ireland: an invasive species on the move. J. Appl. Phycol. 20 (5), 825-832.

Nemecek, T., Kägi, T., 2007. Life Cycle Inventories of Swiss and European agricultural production systems. Ecoinvent Report No. 15a, v2.0. Agroscope Reckenholz-Taenikon Research Station ART, Swiss Centre for Life Cycle Inventories, Dübendorf (Switzerland). 
Pérez-López, P., González-García, S., Jeffryes, C., Agathos, S.N., McHugh, E., Walsh, D., Murray, P., Moane, S., Feijoo, G., Moreira, M.T., 2014. Life cycle assessment of the production of the red antioxidant carotenoid astaxanthin by microalgae: from lab to pilot scale. J. Clean. Prod. 64, 332-344.

Plouguerné, E., Ioannou, E., Georgantea, P., Vagias, C., Roussis, V., Hellio, C., Kraffe, E., StigerPouvreau, V., 2010. Anti-microfouling activity of lipidic metabolites from the invasive brown alga Sargassum muticum (Yendo) Fensholt. Mar. Biotechnol. 12 (1), 52-61.

Raymond, M.J., Slater, C.S., Savelski, M.J., 2010. LCA approach to the analysis of solvent waste issues in the pharmaceutical industry. Green Chem. 12 (10), 1826-1834.

Schaffelke, B., Smith, J., Hewitt, C., 2006. Introduced macroalgae - a growing concern. J. Appl. Phycol. 18 (3-5), 529-541.

Schau, E., Fet, A., 2008. LCA studies of food products as background for environmental product declarations. Int. J. Life Cycle Assess. 13 (3), 255-264.

Sigma Aldrich, www.sigmaaldrich.com (accessed November 2013).

Sutter, J., 2007a. Life Cycle Inventories of highly pure chemicals. Ecoinvent Report No. 19, v2.0. EMPA, Swiss Centre for Life Cycle Inventories, Dübendorf (Switzerland).

Sutter, J., 2007b. Life Cycle Inventories of petrochemical solvents. Ecoinvent Report No. 22, v2.0. ETH Zürich, Swiss Centre for Life Cycle Inventories, Dübendorf (Switzerland).

Vázquez-Rowe, I., Moreira, M.T., Feijoo, G., 2010. Life cycle assessment of horse mackerel fisheries in Galicia (NW Spain): comparative analysis of two major fishing methods. Fish. Res. 106 (3), 517-527.

Walker, D.I., Kendrick, G.A., 1998. Threats to macroalgal diversity: marine habitat destruction and fragmentation, pollution and introduced species. Bot. Mar. 41 (1-6), 105-112. 
Ye, H., Wang, K., Zhou, C., Liu, J., Zeng, X., 2008. Purification, antitumor and antioxidant activities in vitro of polysaccharides from the brown seaweed Sargassum pallidum. Food Chem. 111 (2), 428-432. 